\title{
機械安全制度の導入に伴う機械の使用段階での妥当性確認の考察 一労働安全分野におけるマクロ労働安全の提案—
}

労働安全分野において望ましい安全を達成するために，欧州型機械安全制度の導入を望む声がある．労働 安全は, リスク全体を俯瞰したうえで, リスクの回避, 低減, 移転, 保有などのリスク対応にて, リスクを管理す ることを基本とするシステムであり，機械安全は，リスクを個別に低減することを基本とするシステムである. そこで, リスクマネジメントの観点より, 機械安全制度を労働安全におけるリスク低減策と位置づけることで, 制度を運用する方法を提案する。このための理論的枠組みに，リスクマネジメント原則 ISO 31000:2009を使用 する。このマネジメント内において，現場の労働災害防止対策の妥当性を確認する活動が必要となることを示 す。なお，このマネジメントの目的は，自主的な安全衛生管理活動を支援する社会環境を整えることであり，事 業場で実施されるリスク対応のための手段を，社会制度等で整備することである。ここでは，制度や施策の不 確かさをリスクとして报うことが求められるが, この考え方は従来の労働安全でのリスクの捉え方とは異なる. そこで, 事業場を取り巻く社会環境の不確かさを扱う分野をマクロ労働安全とし, 従来の, 事業場単位で実施さ れる自主的な安全衛生管理活動での不確かさを扱う分野をミクロ労働安全として，区別することを提案する. キーワード：労働安全，機械安全，社会制度，全体最適，妥当性確認

\section{1 はじめに}

労働安全および機械安全分野において, 望ましい「安 全」を達成するための, 仕組みや制度等の社会基盤整備 に関する議論が始まっている。この一環として, 労働安 全衛生総合研究所では, 厚生労働科研費「機械安全規制 における世界戦略へ対応するための法規制等基盤整備に 関する調査研究」にて世界情勢を鑑みつつ日本国内で機 械安全を推進するための法規制及び社会制度のあり方に ついて調査研究を進めている ${ }^{1,2)}$

これに関し日本国内では，機械安全に関する法規制お よび社会制度のあり方として，欧州の機械安全に関する 法規制および社会制度（補足 1参照）に，日本のそれら を完全に整合させる案を支持する声も多いと聞く．しか しながら，こうした意見が対象としている法規制および 社会制度は「機械安全」に限定されたものであり，これ と対をなすはずの労働安全に関する法規制・社会制度へ の言及は少ない.

当然のことながら, 日本の労働安全と欧州の機械安全 制度は, 各々目的の異なる社会システム ${ }^{3)}$ であることか ら，両者の差異を考慮せずに機械安全制度を導入した場 合には, 望む成果が得られないことが予想される.これ を避けるためには，互いの目的や考え方の違いをまず明 確にし, 労働災害防止のための社会的手段として機械安 全制度を導入することが求められる. 加えて, 日本の労 働安全分野には, 適合性評価制度に対する䛊った解釈な どの, いくつかの問題などが存在することから, これら

原稿受付 2015年9月24日（Received date: September 24, 2015） 原稿受理２016年5月17日（Accepted date: May 17, 2016） J-STAGE Advance published date: July 19, 2016

*1 労働安全衛生総合研究所 電気安全研究グループ

連絡先：干204-0024 東京都清瀬市梅園 1-4-6

労働安全衛生総合研究所 電気安全研究グループ 濱島京子

E-mail: hamajima@s.jniosh.go.jp

doi: 10.2486/josh.JOSH-2015-0018-CHO
への対応も同時に必要となる.

そこで本論文では，日本の労働安全分野に欧州型の機 械安全制度を導入する場合に，労働安全分野に求められ る対応について考察し，次のことを述べる。まず，これ まで，機械設備の設計・製造段階での妥当性確認が重視 されていたが, 使用段階での妥当性確認が労働災害防止 の要点であることを示す。次に，この使用段階での妥当 性確認について考察した結果，マクロ労働安全という考 え方に至ったことを示す。

本論文ではまず，日本の労働安全分野に欧州型機械安 全制度（補足 1 参照）を導入する場合の問題点をいくつ か示す。なお, 以後の議論では, 導入の対象とする欧州 型機械安全制度を単に機械安全制度と呼ぶこととする.

次に，機械安全と労働安全における，リスク対応の 違いなどを，国際標準規格を用いて比較する。ここで は，規格の階層構造を踏まえ，同階層間での概念を比較 するよう規格を選定すると, 労働安全のシステムモデル となる規格には, OHSAS 18001 などの労働安全衛生マ ネジメントシステム規格ではなく, 不確かさに基づくリ スク概念を定めたISO Guide 73:2009 (JIS Q 0073:2010) と，リスクマネジメント原則ISO 31000:2009（JIS Q 31000:2010 ${ }^{5)}$ が利用できることを示す。比較の結果, 労 働安全はリスク全体を俯瞰したうえで, リスクの回避, 低減，移転，保有などのリスク対応にて，リスクを管理 することを基本とするシステムであるのに対し，機械安 全はリスクを個別に低減することを基本とするシステム であることを示す.

本論文では, この労働安全のシステムモデルに則り, 機械安全制度の運用と問題点へ対応する方法を検討す る.ここでは, リスクマネジメントの観点より, 労働安 全のシステムのリスク低減策に機械安全制度を位置付け る方法を提案する. また, 特に労働安全分野に求められ る対応として, 妥当性確認と呼ばれる活動が必須となる 
ことを示す。なお，この活動は，ISO 31000:2009では， モニタリング及びレビューと呼ばれるものである.

上記のリスクマネジメントは, 事業場を取り巻く社会 基盤を整備し, 事業場での自主的な安全衛生管理活動を 支援する環境の構築を目的とする.これは従来の, 労働 安全分野におけるリスクマネジメントとは目的及び手法 が異なるものであることから，これを区別するために， マクロ労働安全とミクロ労衝安全の概念を提案する.

\section{2 日本の労働安全分野に欧州型機械安全制度を 導入した場合の問題点}

欧州型機械安全制度の導入目的は, 労働災害防止であ るが, この制度には, 目的の達成を妨げるような問題点 が存在する. 以下にその要点を述べる.

\section{1）機械安全体系が適用困難な機械設備の存在}

機械災害防止の原則は隔離と停止であり, 欧州機械安 全に基づく機械安全国際規格体系 (以後, 機械安全体系 と呼ぶ）は, この原則に基づき, 隔離と停止を可能とす る保護方策をまとめたものである.このため, 産業現場 に存在する，すべての機械設備で実施されるすべての作 業に対して, 隔離と停止に基づく保護方策の適用が可能 であるならば, 欧州型機械安全制度の労働災害防止効果 は高いものとなる、ところが, 実際の産業現場には, 隔 離と停止が困難な機械設備が多数存在し，こうした機械 設備にて重篤な労働災害が発生しやすいことが知られて いる6 ${ }^{6}$.つまり, こうした機械設備に対しては, 機械安 全体系の労働災害防止効果は高くないことから, 機械安 全制度の労㗢災害防止効果は限られたものとなる可能性 がある.

図 1 に, 隔離と停止の可能性の視点より, 機械設備を 分類した模式図を示す。ここで, 図1の区分 $\mathrm{A}$ は機械安 全体系に基づく工学的対策が可能な機械設備である.こ の領域の機械設備では, 機械安全制度での労働災害防止 に確実性が見込まれる。一方，図1の区分 B は，隔離と 停止が困難な機械設備である. この領域の機械設備で は, 労働災害防止対策は人の注意力に依存した伝統的安 全管理に頼らざるを得ず, 災害防止の確実性は, 図1の 区分 $\mathrm{A}$ と比較して低いものとなる。ここで，注意を要す る点は, 機械設備の中には, 実施される作業に応じて, 図1の区分 $\mathrm{A}$ と区分 $\mathrm{B}$ の両方の状態を持つものがある, という点である. 例えば, 区分 $\mathrm{A}$ の例としては, 人の介 在を必要としない自動運転など, 人が運転中の機械の可 動部に近接せずに作業を実行する場合が挙げられる。一 方, 区分 Bの例としては，トラブル処理，保守・点検, 清掃, 修理の作業など, 運転中の機械の可動部を停止さ せずに人が可動部に近接して作業を行わざるを得ない場 合が挙げられる.

この, 図 1 の区分 Aおよび区分 B に関する機械設備で の労働災害の実態を表すものに, 「産業機械設備による死 亡労衝災害 129 件 $\left.^{6}\right\rfloor$ の分析結果がある.

この分析 ${ }^{6}$ では, 設備的要因と作業的要因の $2 つ の$ 側 面から, 根本原因を推定している. 設備的要因に㧍いて

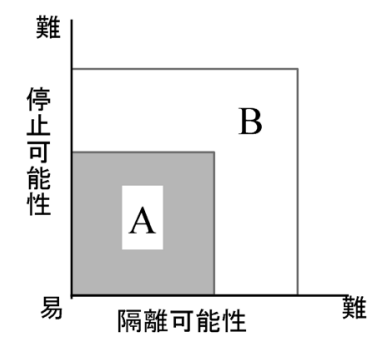

\section{区分A: 機械安全体系の適用が可能 区分B: 機械安全体系の適用が困難}

図 1 機械安全体系の適用性

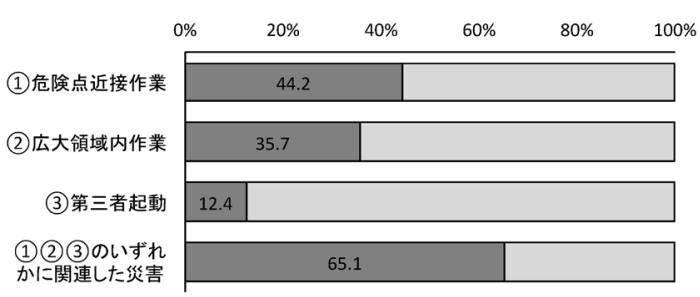

図2 産業機械設備による死亡労働災害発生時の状況 ${ }^{6}(\mathrm{~N}=129)$

は，保護方策の不足・不具合のみを調べた結果，機械安 全体系に基づく保護方策を確実に実施していれば，発生 した死亡労㗢災害の $79.1 \%$ （102件）に対して, 災害防止 効果があったと推察されている.この結果は, 図1の区 分Aにおける，隔離と停止が可能な機械設備における機 械安全体系の災害防止効果と推定される。

しかしながら，作業要因に関する分析では，同じ死亡 労㗢災害 129件のうち 65.1\%（84件）が, 隔離と停止に 基づく保護方策の適用が困難な作業にて発生していたと 推察されている. 図2に, 産業機械設備による死亡労働 災害 129 件 ${ }^{6}$ の分析より，作業要因に関する分析結果を 示す．この分析 ${ }^{6}$ では，危険点近接作業 による死亡災 害が全体の $44.2 \%$ （57件）, 広大領域内作業 ${ }^{\circledR} の$ 死亡災 害が全体の35.7\%（46件）を占めていた。ささらに，これ ら2つに加えて, 他の作業者が誤って機械設備を起動す る第三者起動による災害 $12.4 \%$ （16件）も加味すると， いずれかに関連した災害は全体の 65.1\%（約3分の2）を 占めていた。 こうした作業で, 隔離と停止による保護方 策の実施が困難な理由として, 危険点近接作業では, 「機 械を停止しての作業が技術的に困難であったり, 生産性 や作業性を阻害するために機械を停止したくないなどの 理由から, 既存の保護装置の適用は困難なことがある ${ }^{6} 」$ と指摘されている。 また, 広大領域内作業に関しては, 市販の保護装置では全領域を監視できず, 人の注意力に 依存して安全を確認するというリスクが残ることが，そ もそも根本問題としてあるために, 「作業者が広大領域に 進入した場合の災害防止対策や，他の作業者が誤って機 械を起動したときの災害防止対策として，光線式安全装

\footnotetext{
危険点近接作業とは運転中の機械の可動部に近接した状態で作業を 行う形態の総称である。

、隔離と停止に基づく保護方策の実施が原理的には可能であるが, 監視 領域が広大な故に人の存在を検知する工学的手段（電気的検知保護設 備等）がなく，隔離と停止が実現できない形態の総称をいう。
} 
置，マットスイッチ，キースイッチを始めとする様々な 保護装置が使用されている。 しかし，これらの装置は作 業性を阻害したり, 機械の起動時には作業者の人的注意 力を必要とするなどの理由から, 現場では広く普及する には至っていない6)」と指摘されている.

これより，図1の区分Bに属する機械設備において は，そもそも技術的に機械安全体系に基づく保護方策の 実施が困難である場合と, 技術的には可能であっても作 業上の理由から適用が難しい場合とが存在することがわ かる. このことが, 上に示した死亡労働災害129件の分 析 $^{6)}$ において, 設備的要因の分析では, 機械安全体系に よる労働災害防止効果が $79.1 \%$ と推定される一方で, 作 業的要因の分析では, 機械安全体系の適用が困難な作業 での労働災害が $65.1 \%$ 占めるという，一見，相反する 結果を生む原因となっている.

これらのことより，機械安全体系の労働災害防止効果 は, 隔離と停止が可能な機械設備に対しては, 高い効果 が期待できるが, 隔離と停止が困難な機械設備に対して は効果は不明瞭であるといえ，機械安全制度を導入した としても, 隔離と停止が困難な機械設備による重篤な労 働災害の防止に, 制度が寄与するかどうかは不明な部分 があるといえる。

\section{2）適合性評価制度の労働災害防止効果}

日本の労働安全分野には,「欧州を起源とする機械安全 規格への適合が確認された機械設備を使用すれば労働災 害は防止できる」とする考え方がみられる。しかしなが ら, 機械安全制度での, 個別規格への適合とは労働災害 が発生しないこと（または労働災害が発生する可能性が 極めて低いこと）を意味するものではない.

図3は，製造された機械設備等が，所定の規格の要求 基準を満たしているか否かを確認する関係を, ISO 9000 (品質管理システム) に従って示した図 ${ }^{7)}$ に, 労働安全と の関わりを追加したものである. 図3で, 機械安全の破 線枠内における検証とは「規格で規定される要件への適 合の立証作業 ${ }^{7)} 」 て ゙ あ り$, 妥当性確認とは「使用目的の要

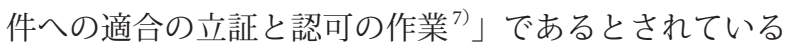
（ここでの認可とは，ユーザによる確認の意味であると 考えられる). 本論文で対象とする適合性評価の意味は, この検証に相当することから, 図3では〈検証〉に適合 性評価を併記している.

先に示した,「個別規格への適合でもつて機械設備が労 働災害防止に十分な状態であるとみなす」とする考え方
が成立するのは，個別規格に規定される内容が，労働災 害防止要件のすべてを満たす場合のみである。しかしな がら一般的に，個別規格が労働災害防止要件のすべてを 満たすことはない.

この理由の一つとして, 機械安全と労働安全の本質的 な目的の違いがある．機械類の安全性を定めた機械安全 国際規格の本質的な目的は，製品の流通である ${ }^{8)}$. 規格 はあくまでも，製品レベルでの安全性を満たすことを目 的として定められる。このため, 規格で扱われる危険源 は，(1)機械設備に存在している，または関連づけられて いると同定された危険源の中で, (2)設計者による対応が 求められ，(3)なおかつ，その対応の内容が合理的に実施 可能として標準化できた危険源, に限らざるを得ない9).

これは見方を変えれば，上記に該当しない危険源を有 する機械設備を，労働災害防止に望ましい状態とするた めには, 現場（労働安全側）での対応を要することを意 味する．労働安全分野にて懸念される事態は，これらの ことが十分に理解されずに，適合性評価の結果が安全性 に対するなんらかの品質保証のように扱われてしまうこ とである.

図1を例として挙げれば，規格への適合を，何らかの 図柄による適合証 (マーク等) の貼付にて表明した場合， 図1の区分 $\mathrm{A}$ および区分 $\mathrm{B}$ のどちらの機械設備に対して も，同一のマークが貼付される．このため，機械設備が 図1のどちらの区分に属するのかをマークから判断する ことはできず，マークが貼付された機械設備の安全性は 皆同じ水準にあるものと䛊解される危険性がある.これ により，労働現場にて，さらなるリスク対応（工学的対 策によるリスク低減等）が求められる場合があることへ の理解が深まらない可能性がある.

適合性評価にかかわるこれらの事項は，機械安全の専 門家や欧州向けに機械設備を設計・製造している事業者 にとっては常識の事項であるかもしれない。しかしなが ら, 平成 18 年にリスクアセスメントが努力義務化され てから約 10年が経過した今日において，リスク概念や リスクアセスメントが国内の労働現場の隅々にまで十分 に普及しているとは言いがたい状況の中で，こうした事 項が正しく理解されない可能性も考えられる.

すなわち，最初に述べた「規格への適合が確認された 機械設備を使用すれば労働災害は防止できる」という前 提条件は成立せず，機械安全制度単体では労働災害を確 実に防止できる保証はない，加えて，適合性評価結果に

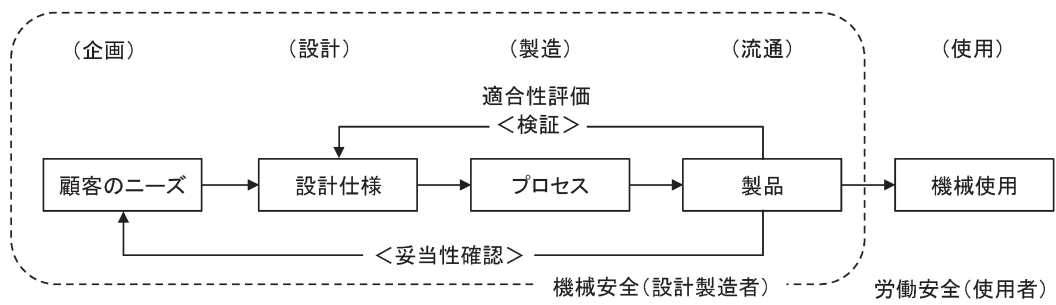

出典: 向殿政男 監修, 安全技術応用研究会 編. 国際化時代の機械システム安全技術. 安全技術応用研究会. 日刊工業新聞社( 2000), p.16, 図1-3を参考に作成

図3 機械安全（製品安全）における適合性評価の範囲

Vol. 9, No. 2, pp. 61-72, (2016) 
対する，労働安全側の誤った解釈により，適切な管理的 対策が実施されない危険性も存在する.

なお, 欧州の機械安全制度 ${ }^{10)}$ での,「適合」には次の 2 つの意味があるとされる.

(1)機械指令への適合（法で定められた要求事項）

(2)規格 (EN/ISO)への適合（1)の適合を推定する根拠）

後者の(2) EN/ISO 規格への適合は, 機械指令への適合 そのものを意味するものではなく，あくまでも「機械指 令への適合を推定させる根拠」として扱われる.このた め, たとえ適用可能な個別規格が存在していたとして も, リスクアセスメントの実施は必須であり, 規格に規 定されていない危険源等があればリスク低減を図ること が求められる. EUにおいては, 個別規格は機械指令へ の適合方法を示した参考事例としての扱いであり, 機械 設備の安全性を個別規格のみに依拠してはならないとの 考えであることがわかる. 機械安全制度の導入において は，欧州におけるこの意味の違いを考慮すべきである.

\section{3）制度運用組織で予想される人的資源等の不足}

本論文では, 機械安全制度の運用を担う労働安全組織 の1つは国（労衝安全衛生行政）と考える. 労働災害防 止を社会規模で達成するために, このことは, 自明なこ とであるかもしれない.しかし, 国が機械安全制度の運 用で担う役割を明確にし，これを社会に示さなければ, 現在の日本においては, 国が目指す労働災害防止の達成 は難しいと考えられる.

国が担う役割に関して言えば, 事業場における労働安 全衛生の確保は, 国が果たさなければならない, 社会制 度としての役割のひとつであり, 仮に機械安全制度を導 入するならば，国際標準に対応した労働安全衛生に関す る保護方策の実施が要求される. このとき, 労㗢安全衛 生に関する保護方策の実施状況を, 機械安全国際規格の 内容を基に評価することも想定される。 そして, 国が事 業者に対して支援を行う場合は, 機械安全国際規格を引 用することが考えられることから, 現場の妥当性確認を 担う人は, 機械安全国際規格や機械安全技術を熟知し ていることが求められる。 しかし，これらの知識や技術 を, 数日程度の講習で習得することは不可能であり, 教 育には相応の時間を要することから, ぞのように人材を 育成するかが問題となる.

これらのことより, 労働安全分野に機械安全制度を導 入するには, 制度を運用する母体となる国の状沉を考慮 した対応も, あわせて検討しなければならない，もし仮 に, 運用に十分な資源等が確保できない場合は, 機械安 全制度の運用は困難となり, 本研究で想定する望ましい 労働安全が得られないことが予想されることから, 制度 運用に係る資源等の不足も，機械安全制度を運用するう えでの問題点となりうる.

\section{4）リスク概念に基づく社会制度体系の不在}

機械安全制度の導入に関する議論では, 機械安全を日 本に普及させる方法のひとつとして, 有識者等より労災 保険料率に労㗢災害の発生状況を反映する制度構築が提 案されることがある ${ }^{11,12)}$.
しかし，リスクマネジメントの概念に照らし合わせれ ば13)，保険とは通常，被災者が保有するリスクの移転ま たは保有の手段として準備されるものであり, 制度の普 及促進のためにあるものではない.これに対し, 機械安 全が普及すれば機械災害が減るために, 労災保険制度運 用上のメリットがあるとする声もある。しかし，機械安 全の適合性評価が労働災害防止に必ずしも寄与するもの ではないことは，先に示したとおりである，さらに，労 災保険制度は, 機械安全が主たる対象とする製造業に 限ったものではなく, 林業, 建設業などを含む国内全て の産業に関わる制度である. 機械安全制度の導入および 推進だけを目的として, 労災保険制度の改定等を検討す ることは避けなければならない。

機械安全制度は, リスク低減のための手段を広く社会 制度として供給するものと考えられる。このほかのリス ク対応についても，その手段を供給するための社会制度 などが存在するはずであり, 先の労災保険は, 適切なり スク低減を図った後の残留リスクの移転先として位置づ けられる。

このように，事業者がリスク対応を選択できる手段を 社会制度などの社会的基盤として提供し，その全体構成 とリスク対応法をひとつの体系として構築し, 示してい くことが必要と思われるが, リスク概念に基づく対応の あり方についての全体像は解明されていない.

\section{3 国際標準規格を用いた機械安全と労働安全の比較}

機械安全と労働安全は, 各々リスクを扱う社会システ ムであるが, リスクの概念や対応の方法には違いが存在 する，以下に，国際標準規格を用いてその差異を考察 し, 問題の根源を推定する.

\section{1）機械安全と労働安全のシステムモデル}

機械安全と労働安全における, リスクや安全に関する 概念などの違いを比較するため, システムモデルとし て，国際標準規格を利用する。なお，国際標準規格には 階層構造が存在することから, 同階層間で比較ができる よう, 両分野の規格を選定する.

機械安全の国際標準規格は, 安全側面を規格へ導入 する際の指針を示したISO/IEC Guide 51:1999（JIS Z 8051:2004) ${ }^{14)} * *$ および, 機械類の安全性として設計のた めの一般原則とリスクアセスメント及びリスク低減を定 めたISO 12100 （JIS B 9700）を使用する.

一方, 労働安全の国際標準規格には, リスクマネ ジメントの用語を定めたISO Guide 73:2009（JIS Q 0073:2010) ${ }^{4)}$ および, この用語の概念を内包し, リス クマネジメントの原則を定めたISO 31000:2009（JIS Q 31000:2010) $)^{5)}$ を使用する。 ここで, 労衝安全衛生分野 でよく知られている国際的な規格である，労衝安全衛生 マネジメントシステムOHSAS 18001 を使用しない理由

\footnotetext{
**ISO/IEC Guide 51は2014年に改訂第3版が発行されている.しかし 本論文執筆時点にて第3版のJIS Z 8051 がまだ発行されていないこと から，本論文では1999年に発行された第2版であるISO/IEC Guide 51:1999（JIS Z 8051:2004）を引用する.
} 
は，階層構造上，この規格がISO 9000 や ISO 14000 と同 階層の個別規格に相当すると考えられるためである。こ れに対し, ISO 31000:2009はすべてのマネジメント規格 の基本規格として位置付けられており，個別規格である OHSAS 18001の上位規格として ISO 31000:2009が存在 する.

\section{2) システムモデルの比較}

表 1 に, 国際標準規格を用いた労働安全と機械安全の 比較を示す。

まず, 労働安全 (ISO Guide 73:2009) と機械安全 (ISO/IEC Guide 51:1999) とでは, リスクの概念が異な る. ISO Guide 73:2009でのリスクの定義は「目的に対 する不確かさの影響」であり, 安全分野でよく知られ る, ISO/IEC Guide 51:1999での定義である「危害の発 生確率及びその程度の組合せ」よりも概念が広い，この ISO/IEC Guide 51:1999では, リスクは, 危害（労働災 害の場合は傷害や疾病が対象）を引き起こす潜在的根源 である危険源から生ずる, と考える。一方, ISO Guide 73:2009では, リスクは, 組織の目的との関係で生ずる, と考える.たとえば，目的が労働災害防止である場合， 対策の労働災害防止効果に不確かなことがあれば，この 不確かさによる影響がリスクとみなされる．仮に，この 対策が，確実に労㗢災害を防止できるものであるなら ば, 不確かさは限りなく小さくなり, リスクもまた，限 りなく小さくなる。 この不確かさに関して, ISO Guide 73:2009では, その定義を「事象, その結果又はその起こ りやすさに関する, 情報, 理解又は知識が, たとえ部分 的にでも欠落している状態」としており ${ }^{4)}$, リスクは不 確かさから生ずるという考えを示している.これより， 労働安全分野 (ISO Guide 73:2009) でのリスクへの対応 とは，概念的には，不確かさへ対応することと考えられ る.

安全の定義に関しては, ISO/IEC Guide 51:1999では 「受け入れ不可能なリスクがないこと」であるが, ISO Guide 73:2009では, リスクそのものが組織の定める目 的との関連で定まるため, 安全に関する定義はない，た だし，労働安全の目的は労働災害防止と考えられること
から，筆者らは，労働安全分野での安全の定義を，“未然 防止のための仕組みと戦略 ${ }^{15)}$, , と定めている.

リスク対応においては，ISO/IEC Guide 51:1999が損 失の最小化を目的として，リスクを低減させるための方 策に限定しているのに対し, ISO Guide 73:2009では, リ スクの修正を目的として, リスク低減だけでなく, 回避, 移転, 保有などの対応を含めており, ISO/IEC Guide 51:1999よりも選択肢が広い．この，ISO Guide 73:2009 でのリスク対応の選択肢の広さは, リスク全体を俯瞰し たうえで，各々のリスクが全体に及ぼす影響を鑑みて対 応する, 全体最適の視点を示しているものと思われる. 労働安全分野での選択肢を例に挙げれば，機械安全など の工学的対策はリスク低減方策に, 労災保険制度は, 適 切なリスク低減を図った後の残留リスクの移転策として 捉えることができる.

リスクを運用し管理する，という概念においても，労 働安全と機械安全では差異がみられる。規格の名称の 違いにも現れているように, 労働安全では, 組織によ るリスクの運用管理（マネジメント）の概念が基盤にあ るのに対し，機械安全にはこのような概念はない，ISO 31000:2009では, リスクマネジメントを「組織や活動 の目的を達成するために不確定性を運用管理する仕組 み ${ }^{16)} 」 と し, 「$ 組織の内外の状況を踏まえ, 組織目的に 影響を与える可能性としてのリスクを特定してから対応 することまで」を含むものとしている ${ }^{16)}$.このために， ISO 31000:2009は, リスクマネジメントプロセスに関す る標準だけでなく，「枠組み」として，このプロセスを 管理するための組織の運営管理体系についても考元方等 を提供している ${ }^{16)}$. 一方, 機械安全国際規格（ISO/IEC Guide 51 およびISO 12100 など）には，効果的，効率的 にリスクを運用管理するための組織運営は含まれていな $\left(^{16)}\right.$. この理由として, 機械安全は, リスクを自らの内 部に保有せずに，適切なリスク低減を図るとともに，残 留リスクに対しては外部に移転することを前提としてい るためと考えられる.

機械安全と労㗢安全とでの, 目的の達成具合を評価す る方法にも違いがみられる。機械安全では，リスク低減

表 1 国際標準規格を用いた機械安全と労働安全の比較（ISO/IEC Guide 51:1999 ${ }^{14)}$ およびISO Guide 73:2009 ${ }^{4)}$ )

\begin{tabular}{|c|c|c|c|c|}
\hline & \multicolumn{2}{|l|}{ 目標 } & 戦略 & リスク概念 \\
\hline $\begin{array}{l}\text { ガ } \\
\text { イ } \\
\text { ド } \\
51\end{array}$ & \multicolumn{2}{|c|}{$\begin{array}{l}\text { 製品の円滑な流通 } \\
\text { 安全の定義 : 受け入れ不可能なリスクが } \\
\text { ないこと }{ }^{14)} \\
\text { リスクの定義 : 危害の発生確率及びその } \\
\text { 危害の程度の組み合わせ }{ }^{14)}\end{array}$} & $\begin{array}{l}\text { 機械安全 } \\
\text { 個別最適 } \\
\text { 隔離と停止が基本 }\end{array}$ & $\begin{array}{l}\text { 個別最適 } \\
\text { リスクアセスメント（隔離と停止) } \\
\text { リスク対応 : 低減 } \\
\text { 検証 : 適合性評価 }\end{array}$ \\
\hline \multirow{2}{*}{$\begin{array}{l}\text { ガ } \\
\text { イ } \\
\text { ド } \\
73\end{array}$} & $\begin{array}{l}\text { 労 } \\
\text { 働 } \\
\text { 安 } \\
\text { 全 }\end{array}$ & $\begin{array}{l}\text { 重篤な労働災害の根絶 } \\
\text { 安全の定義: 未然防止のための仕 } \\
\text { 組みと戦略 }{ }^{15)}\end{array}$ & $\begin{array}{l}\text { 労働安全（危険源の多様性） } \\
\text { 全体最適 } \\
\text { 隔離と停止が困難な機械設備の存在 } \\
\text { （危険点近接作業, 広大領域内作業 } \\
\text { など） }\end{array}$ & $\begin{array}{l}\text { 全体最適 } \\
\text { 総合的リスクマネジメント } \\
\text { リスク対応 : 不確かさへの対応 } \\
\text { 検証 : 妥当性確認 }\end{array}$ \\
\hline & 般 & $\begin{array}{l}\text { リスクの全体最適 } \\
\text { リスクの定義 : 不確かさ }\end{array}$ & より普遍的な全体最適 & 全体最適のリスクマネジメント \\
\hline
\end{tabular}

Vol. 9, No. 2, pp. 61-72, (2016) 
を定めた機械安全国際規格への適合を評価する，いわゆ る適合性評価が主体となるのに対し，労働安全では，リ スク対応が労働災害の未然防止（組織の目的）に望まし いものであるか, その妥当性を確認することが求められ る. この確認は, ISO 31000:2009での用語では, “モニ タリング及びレビュー”に該当するが，表1では適合性 評価の用語と対比しやすいよう, 妥当性確認と表してい る.

以上の事項より，機械安全（ISO/IEC Guide 51:1999） と労働安全（ISO Guide 73:2009）では, リスク概念およ びその対応において, 戦略に違いがみられる. 機械安全 が，機械設備ごとに，個別にリスクを低減し，そのリス クを外部へ移転することを前提とした個別最適型のシス テムであるのに対し, 労働安全は, 組織に存在する多様 なリスク全体の最適化を前提とする全体最適型のシステ ムと捉えられる。

\section{3）問題の根源にあるシステムモデルへの理解不足}

日本の労働安全分野に, 欧州型機械安全制度を導入す る場合の問題点が生ずる原因として, まず, 表 1 に示し たようなシステムの違いが, 労働安全分野にて明確に認 識されていない点が挙げられる. 特に, 問題点1）およ び2）で示した事項は, 機械安全の個別最適性に起因す る問題であり, 労働安全分野では, この個別最適性が十 分に理解されていないものと思われる.

また, 労働安全のシステムモデルが正確に理解されて いないことも, 問題の根源として挙げられる. 労衝安全 は，不確かさをリスクとみなし，これをマネジメントす ることを基本とするシステムである. このため, 労働安 全分野は, 自らのシステムモデルに則った方法で, 機械 安全制度の導入に関する問題解決を図るべきと考える。

先の比較において, 労働安全の基盤として設定した ISO Guide 73:2009では, 目的達成の阻害要因となりか ねない不確かさを，組織活動におけるリスクとみなす。 これはつまり, 機械安全制度の運用を, 労働安全分野で の事業とみなせば, 先に示した問題点は, 事業の目的達 成に影響を与えるリスクとして，捉えることができる。

すなわち, 機械安全制度を導入するためには, 労働災 害防止にかかわる社会制度などの不確かな事項をリスク として把握し，これを管理する“リスクマネジメント” が労㗢安全分野に求められる, といえる. 言い換えれ ば, このリスクを運用管理することが, 労働安全が担う べき機械安全制度の運用そのものとなる.

そこで, 労働安全のシステムモデルと仮定したISO 31000:2009を用いて, 機械安全制度の問題点に対応する 方法を以下にて検討する.

\section{4 機械安全制度導入における問題点への対応}

\section{1）リスク概念に基づく社会制度等体系への対応}

ISO 31000:2009では, リスクは組織の目的との関係で 定まるとしている，そこで, 機械安全制度など, 労働災 害防止に係る制度を運用する組織（ここでは国を想定） の目的を次のように再定義する.
まず，本論文の冒頭にて，機械安全制度の導入目的は 労働災害防止であると述べたが, 労働災害防止は制度が 達成するのではなく, 制度を利用して事業者（機械設備 の設計・製造者や使用者）が達成するものである。そ己 で, 組織の目的を, 法規制や社会制度などを含む, 事業 者を取り巻く社会環境が事業場での安全衛生管理活動に とって, 望ましいものとなるよう, 社会環境全体の最適 化を目指すこと，と定義する．この目的の下では，社会 環境の不確かさがリスクとみなされる。例えば，機械安 全制度が社会制度化されていないことが, 事業場でのリ スク低減が進まない要因となり, 労働安全分野全体での リスクとみなされるならば，リスク低減策として，機械 安全制度を導入することが考えられる.リスクマネジメ ントは，これを実現するための手法として用いる。これ により, リスク概念に基づく社会制度等の体系を示すこ とができるものと考える.

図4は, ISO 31000:2009でのリスクマネジメント原則 に, リスク対応として機械安全制度を運用するための考 え方を併記したものである. 図4 上段の「全体最適の理 論的枠組み」において, 機械安全制度などの, 労働災害 防止に係る制度の提供扔よび運用業務をプロセスとみな し, 制度を運用する組織を枠組みと位置づけることで, リスク対応と社会制度の関係を示すことができ, 制度運 用組織の問題点も検討することが可能となる。つまり, 本論文で最初に示した, 日本の労働安全分野に欧州型機 械安全制度を導入した場合の問題点へ対応を議論するこ とが可能となる.

\section{2）制度運用組織の人的資源等に関する問題への対応}

図4の上段「全体最適の理論的枠組み」において黒線 枠囲みにて記載した「原則」「枠組み」「プロセス」の3 種 類が, ISO 31000:2009にて示されているリスクマネジメ ント原則の内容である ${ }^{5)}$.ここで, 原則とは, 組織が理 解すべきリスクマネジメントの理念, および考え方と行 動の原則を示したものである ${ }^{16)}$.

次いで，枠組みは，プロセスを管理するための組織の 運営管理体系についての考え方などを示したものであ る.ここでは特に, リスクマネジメントをそのプロセス に沿って実施する前に, 組織が置かれている状況を評価 し, 理解したうえで, リスクマネジメントを有効に機能 させる枠組みを構築することが重視されている ${ }^{16) .}$

これを本論文での議論にあてはめれば，問題点3）で 示した制度運用組織で予想される人的資源等の不足が, この枠組みで検討すべき事項に該当し, 制度運用を担う 組織の体制や人員などについて, リスクマネジメントプ ロセスの実施に先立って事前に検討することが求められ ることとなる。

\section{3）リスク対応における機械安全制度の位置付け}

リスクマネジメントプロセスでは, リスクアセスメン トに基づいてリスク対応を選択し実施する.

ここでは, たとえば, 労働災害件数や全労働損失日 数 ${ }^{17-19)}$ などの評価指標を用いて, 労働災害全体のリス クを把握しこのリスクに対する評価をもとに，社会的 

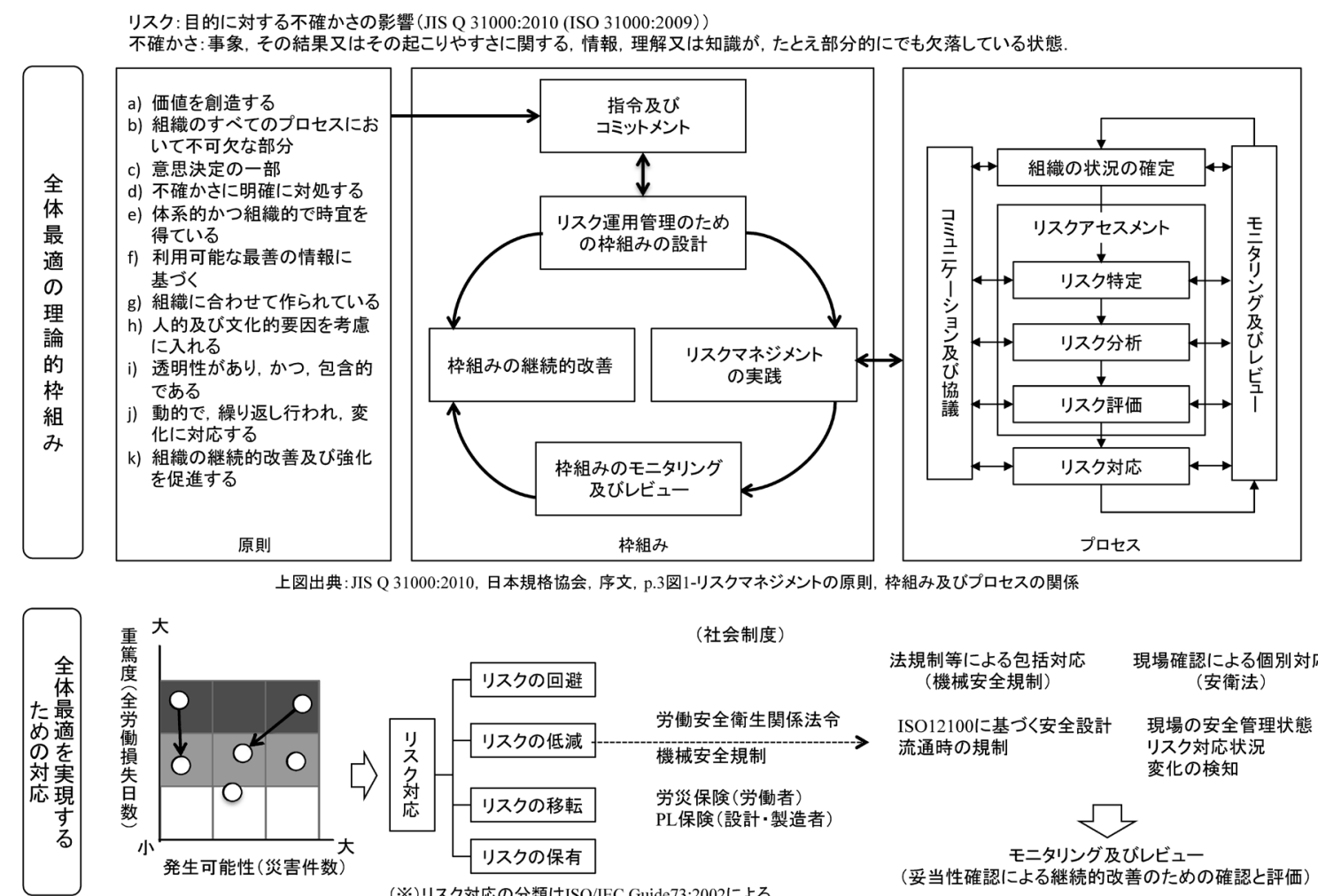

現場確認による個別対応 (機械安全規制) (安衛法)

SO12100に基づく安全設計＼cjkstart現場の安全管理状態 㐬通時の規制つく宔設計現场の安全管效状 変化の検知

(※)リスク対応の分類はISO/IEC Guide73:2002によよる

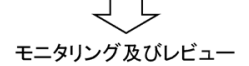

（妥当性確認による継続的改善のための確認と評価）

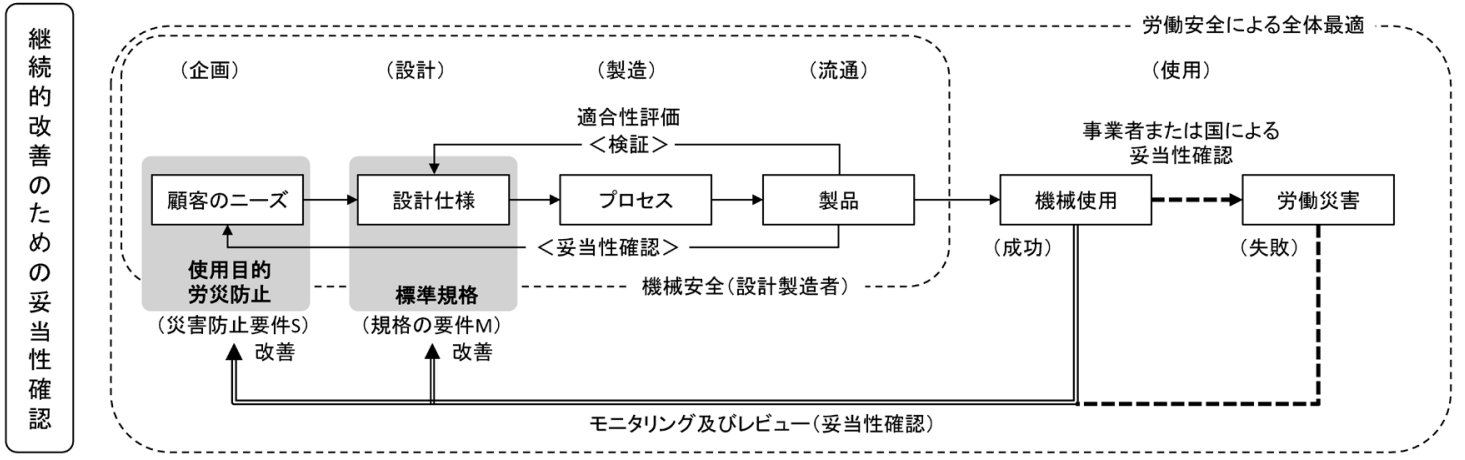

図 4 ISO 31000: 2009 （JIS Q 31000:2010）を基盤とした労㗢安全分野における全体最適対応の概念

に整備すべきリスク対応策を決定する。図4に示すよう に，リスク低減策には，機械安全制度のほかに，労働安 全衛生法や労働安全衛生規則などが該当し, (適切なリス ク低減を図った後の）残留リスクの移転策として，労災 保険制度が存在する。

このように，リスク対応策の考え方に基づいて社会制 度の役割を検討していくことで, 問題点 4）として指摘 した，リスク概念に基づく社会制度の体系を示していく ことができるものと思われる。なお，図4でのリスク対 応では，機械安全に関する制度のみを挙げているが，実 際の運用においては, 建設や化学など他の労働安全分野 での方策が含まれる。すなわち，ここでは，労働災害リ スク全体を俯瞰したうえで対応を決定する, 全体最適の 視点が求められる.

\section{4）妥当性確認による適合性評価制度への対応}

問題点 1）および2）で指摘した, 機械安全体系が適用 困難な機械設備と適合性評価制度の問題点とは, 「機械 安全制度は機種ごとでの個別のリスク低減を前提として
いるため，適合性評価の結果は機械設備が労働災害防止 に望ましい状態であることを一律に保障しない」ことで あった.この, 個別に最適化された状態を, 労働安全の 視点から望ましい全体最適の状態に改善することが，問 題点への対応となる。このための妥当性確認制度を以下 に提案する。

妥当性確認とは，ISO 31000:2009（図4）での，モニタ リング及びレビュー ${ }^{\dagger \dagger}$ 該当するものであり，モニタリ ング及びレビューは，リスクマネジメントを継続的に改 善していくために，枠組みやプロセスの状態を監視し， 妥当性や有効性を確認する活動である．機械安全と労働 安全の比較を示した表 1 では，妥当性確認と表現したこ とから，以下においてもこれを使用する.

† ISO 31000:2009 ではモニタリングを「要求または期待されたパフォー マンスレベルとの差異を特定するために, 状態を継続的に点検し，監 督し，要点を押さえて観察し，又は決定すること（2.28）」とし，レ ビューを「確定された目的を達成するため, 対象となる事柄の適切 性, 妥当性及び有効性を決定するために実行される活動 (2.29)」と定 めている.

Vol. 9, No. 2, pp. 61-72, (2016) 
図4に示した妥当性確認の図は, 図3に労働安全分野 での妥当性確認を追加したものである.ここで, 図4の 「継続的改善のための妥当性確認」に記載した災害防止 要件 S とは, 労働災害防止に関する諸条件（安全要求） の集合を表し, 規格要件 M とは, 機械安全制度における 標準規格での規定内容の集合を表すものとする．この， 災害防止要件 $\mathrm{S}$ と規格規定要件 Mの関係を図 5 に示す。 また, 図4での顧客のニーズには, 法令遵守を含む, 労 働災害防止に関する安全要求「労働災害が起きないこと （または, 労働災害が発生する可能性が低いこと）」が含 まれるものとする.

ここで, 顧客による安全要求「労働災害が起きないこ と」を適合性評価単体で立証することができるのは, 図 5 （a）のように, 規格要件（M）が災害防止要件（S）を 完全に満たす（包含する）場合のみである. これとは逆 に, 図 5 (b) のように規格要件 (M) が災害防止要件 (S) を完全に満たさない場合には，労働災害が防止できるこ とを適合性評価単体では立証することはできない.

一般的に，標準規格の要件（M）は災害防止要件（S） のすべてを満たしてはいない. このため, 機械設備にて 労働災害が発生する可能性がないかを個別具体的に確認 することが必要となる. つまり, 妥当性確認では, 機械 安全制度による機械設備のリスク低減状況の確認に加え て, 事業場での残留リスク対応が適切であるか, その実 態も併せて確認することが求められる.

妥当性確認の結果, 災害防止要件 (S) や規格要件 (M) の内容を改める必要がある場合には, 改善を図ることが 求められる. これが図 4 における妥当性確認での継続的 改善に相当する。つまり, 要件 (M) が可能なかぎり要

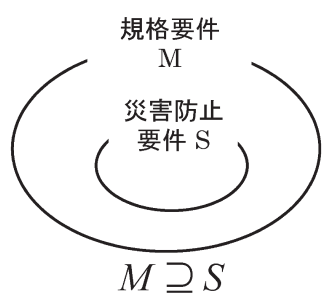

(a) 規格規定内容が労災防止条件 の全てを満たす場合

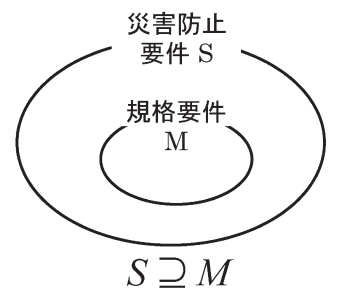

(b) 規格規定内容が労災防止条件 の一部を満たす場合
図 5 労働災害防止要件と規格要件との関係
件（S）を満たすことが，妥当性確認による機械安全制 度の問題点 (不確かさ) への対応であり, 継続的改善と なる。なお，この妥当性確認は，労働災害が発生したと きにも，再発防止の観点から実施されなければならな い，再発防止対策を水平展開するためには，災害防止要 件（S）や規格要件（M）にその内容を反映することが求 められるためである.

ここで, 労働安全衛生関係法令を災害防止要件（S） に，機械安全国際規格を規格要件（M）に位置づけるな らば, 妥当性確認は, 労働安全衛生関係法令や機械安全 国際規格の内容を，より望ましいものに継続的に改めて いくことを意味し，これは同時に，リスク対応を継続的 に改善していくことを意味する。これより，機械安全制 度を運用するためには，この妥当性確認制度があわせて 必要となることがわかる。

\section{5 マクロ労働安全の提案}

労働安全分野におけるリスクの概念や対応戦略は, ISO Guide 73:2009およびISO 31000:2009を基盤とする ことを提案したが, ここでの不確かさに基づくリスクの 概念は，これまでの労働安全分野でのリスクの考え方と は若干異なるものである. 危険性又は有害性等の調査 (労働安全衛生法第28条の2) や, 労働安全衛生マネジメ ントシステム (OHSAS 18001 など) で扱われるリスクの 概念は，ISO/IEC Guide 51:1999 と同じく，危害に基づ くためである.

このことは, 労働安全分野には，2種類のリスク概念 が存在することを示唆している. 本論文では，これらを 区別して报うために，マクロ労働安全とミクロ労働安全 の概念を提案する.

\section{1）組織の規模と目的に応じた区分}

ISO 31000:2009では，リスクは目的を設定してはじめ て定義できるものであることを示しており，この目的に は, 組織が目指す様々な目標も含まれるとされる ${ }^{16)}$ 。そ こで, 図6に労働安全分野における組織の規模別に, 目 的や対象とするリスクの違いなどを示す。

組織が事業場の場合には, 事業場内の労働災害防止が 目標となることから，危害のひどさと発生確率を下げる ための，労働災害防止対策の不確かさがリスクとして考

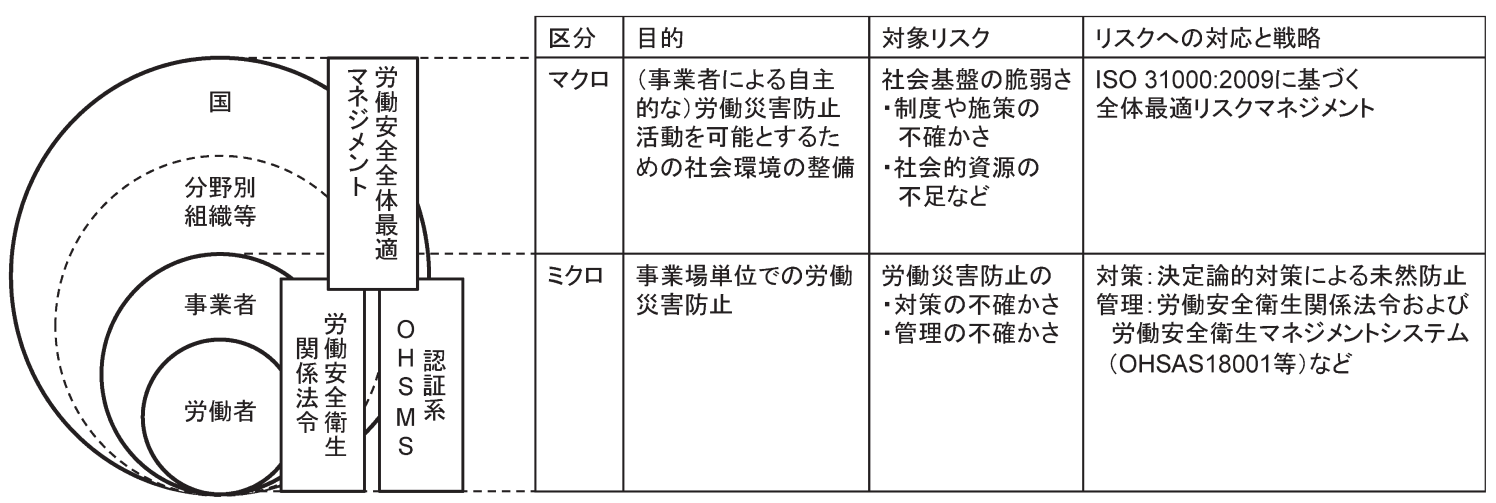

図6 マクロ労働安全とミクロ労働安全 
えられる. 一方, 組織が国 (労働安全衛生行政) の場合 には，目標は国内全体の労働災害防止であることから， リスクは，本論文で指摘したような，制度や施策の不確 かさが該当すると考えられる。本論文では，前者をミク ロ労働安全, 後者をマクロ労働安全と区分する.

\section{2）ミクロ労働安全}

従来の, 事業場や労働者を対象とした, 労働安全衛生 の取り組みや体系の区分を，ミクロ労働安全と呼ぶこと を提案する. この区分は, 労働安全衛生関係法令や労働 安全衛生マネジメントシステム（OHSMS）を軸として, 事業場単位での, 自主的な安全衛生管理活動を基盤とす るものである. この, ミクロ労働安全の目的は, 個別事 業場を対象とした労働災害防止である.

図6に示すように，ミクロ労働安全の分野では, 事業 場個別の活動を基本とすることから，対象とするリスク には, 対策に関するものと, 管理に関するもの, の2種 がある. 前者の対策に関しては, 事業場内に存在する, 個々の危険源より生ずる可能性のある労働災害を, 確実 に防止することが対策の目標であることから, 対策の不 確かさがリスクとなる。このリスクへの対応において は, 対策の不確かさを減少させる方策を選択することが 戦略として求められる。このための方策に, ガードや安 全装置の設置などの決定論的対策に基づく未然防止策が ある。

後者の管理に関しては, 事業場における, 安全衛生管 理の体制や活動が，前者の労働災害防止対策を促進する ような職場環境を形成しているかどうか, が不確かさに 相当する. このリスクへの対応においては, 労働安全衛 生関係法令に定められる安全衛生管理体制や労働安全衛 生マネジメントシステム（認証系 OHSMS）などがある.

\section{3）マクロ労働安全}

本論文では，ミクロ労働安全の実行を支える，社会基 盤（社会環境）整備を目的とする区分を，マクロ労働安 全と呼ぶことを提案する.

日本の労働安全の社会的な目標は, 国内全体の労働災 害防止であるが, 具体的な労働災害防止対策を実際に講 ずるのは事業場である. このため, 事業場が行う自主的 な安全衛生管理活動の中で, 望ましい労働災害防止対策 を講じることができるように，法規制や社会制度の整備 および運用，教育環境の提供など，労働者や事業場をと りまく社会基盤（社会環境）を整えることが, マクロ労 働安全の目的である。例をあげると, 本論文で対象とし た, 機械安全制度の導入とは, ミクロ労働安全分野で実 施されるリスク低減策を, 社会制度として提供するもの であり, また, 労災保険制度は, 適切なリスク低減後の 残留リスクの移転のための社会制度として提供するもの である。

こうした社会制度がなければ，ミクロ労働安全分野で の安全衛生水準は向上しないことから, マクロ労働安全 が対象とする不確かさは, 社会基盤の脆弱さ, と考えら れる. この区分における, リスク対応と戦略についての 体系は現状では十分には解明されておらず, 今後の研究
を要するが，リスク全体を俯瞰したうえでの対応が求め られることから, ISO 31000:2009に基づく全体最適マネ ジメントが該当すると考えられる.

\section{6 今後の労働安全のあり方}

今後の日本の労働安全においては，従来のミクロ労働 安全に基づく対応だけでなく，マクロ労働安全の観点か らの対応や研究も重要と考えられる.この中でも特に, 継続的改善を図るための妥当性確認と, 法規制や社会制 度を含む社会環境の整備について，検討が必要と思われ る. 以下に, これらの要点を述べる.

\section{1）妥当性確認の支援}

今後の労働安全においては, マクロ労働安全の立場よ り，国による妥当性確認の支援を検討すべきであると考 える，妥当性確認には，図4 に示すように，事業者また は国による2種類の方法があるが，事業者による妥当性 確認は，あくまでも事業場内の確認に限られる.

また, 事業者による妥当性確認の内容は, 労働安全衛 生関係法令が定めた最低基準を満足しているかを自ら確 認するとともに，自主的な安全衛生管理活動にて実施さ れる機械設備への安全対策の妥当性を確認するものであ る，ただし，この確認は，事業者が自ら個別に定める基 準等に基づいて妥当性が判断されるが，基準等そのもの が事業場ごとに異なるものであることから，対策や安全 衛生管理の水準は，事業場間で差が存在する。すなわ ち, 機械安全と同様に, ミクロ労働安全にも個別最適性 が存在する。この差を解消し, 国内水準全体を向上させ る全体最適の役割を担うのが，マクロ労働安全での妥当 性確認である，これには，国内事業場の安全衛生管理状 態を，広く把握し，統一的な見解を有することのできる 組織や人が，妥当性確認を担うことが望ましいことか ら, 例えば, 労働安全衛生総合研究所の職員や専門的知 見を備えた労働基準監督機関の職員などが，妥当性確認 を支援することを提案する。なお，ここでいう支援の中 には, 特に重要な業務として, 安全衛生管理に関する事 業場間の水準差を解消するための調整業務も含まれる.

\section{2）自主的対応を支援する社会基盤整備}

ミクロ労働安全での, 自主的な安全衛生管理活動は, 自らの努力だけでできるものではなく，事業場をとりま く環境に影響される，と思われる。このため, マクロ労 働安全の視点からは，国が果たす役割として，“事業場 が，自主的に安全衛生管理活動ができるための社会環境 を，基盤として整えること”，と考えられる。

ミクロ労働安全の分野では, リスクアセスメントを軸 とした, 自主的安全衛生管理活動の促進が重要な課題と なっているが, 中小規模の事業場での取り組みは遅れて いると言われる。この背景として，事業場をとりまく社 会環境が未だに法規遵守型であり，自主的な活動を支え る環境が整っていないことが，仮説として考えられる.

労働安全衛生分野における自主的活動とは, 決められ たこと（法規）を実施する（遵守）だけでなく，自ら問 題を発見し，解決すること，である．マクロ労働安全で

Vol. 9, No. 2, pp. 61-72, (2016) 
は, 問題の発見と解決に必要な資源を社会は提供してい るか，を問題とする．このための資源には，例えば，労 働災害防止の考え方や機械安全に関する知識や技術が習 得できる環境があるか, 機械安全と労働安全に精通した 専門家に支援や助言を求めることができるか, 保護方策 や安全衛生管理に関して参考にできる成功事例が豊富に あるか，などがある。こうした資源が簡単に利用できる 社会的環境が, 事業者による自主的な活動を可能にし, 促進すると思われる．事業場が適切なリスク対応をとる ために, 必要とする選択肢（問題解決のための資源）を, 社会が提供していることが重要であり, 今後の労働安全 においては, 特に中小規模の事業場に対して, こうした 資源を整備していくことが必要と考えられる.

\section{7 おわりに}

本論文では, 日本の労働安全分野に欧州型機械安全制 度を導入するための考察を通じて, 使用段階での妥当性 確認が労働災害防止のための要点であること, 社会基盤 の整備を目的とした新たなリスクマネジメントの概念と して, マクロ労働安全が必要となることを提案した. 以 下に，考察結果をまとめる.

1）労働安全でのリスクは, ISO Guide 73:2009での 不確かさの概念に基づく，一方，機械安全でのリスク は, ISO/IEC Guide 51 での危害の概念に基づく. 機械 安全制度を労働安全分野に適用する場合は, この2つの 概念を扱う。機械安全制度は, 危害に基づくリスクを社 会全体で適切に低減するための手段として使用する．た だし, 機械安全制度には, 手段の効果に関して不確実 な側面があり, また, 制度を運用する労働安全組織にも 人員不足等の問題がある. これらの問題は, ISO Guide 73:2009での不確かさに相当する. つまり, 労働安全分 野で管理すべきリスクとして問題を認識すべきであり, このリスク管理の理論的枠組みとして, ISO 31000:2009 が利用できる。

2）問題への対応には，少なくとも(1)妥当性確認制度, (2)制度運用組織の環境整備, の実施が必要である. (1)で は, 産業現場の確認を通じて機械安全制度のリスク低減 効果を把握し, 機械安全国際規格の内容が労働災害防止 に望ましいものとなるよう, 規格規定内容を確認し, 産 業現場の情報を規格等に反映する。 これにより, 機械安 全制度の継続的改善を図る. (2)では, 機械安全制度の運 用や妥当性確認の支援に要する人的資源や組織を整え る.

3）上記2）の対応では, 労働安全をとりまく社会環 境全体を俯瞰したうえでの検討を要するが, 現在の労働 安全分野には, このような議論を展開するための概念や 理論がない, このため, 事業場での自主的な安全衛生管 理活動が重視される社会環境の中で, 労働安全衛生行政 や労働基準監督機関ならびに労働安全衛生に関する専門 機関や研究者・専門家等が担う役割や連携が見えにくく なっている. そこで, 社会環境の不確かさをリスクと捉 える分野をマクロ労働安全と定義し, 国を含めた組織の
役割と社会基盤整備の議論を展開する必要性を示した。 また, 従来の, 事業場単位で実施される自主的な安全衛 生管理活動での不確かさをリスクと捉える分野をミクロ 労働安全, と区別することを提案した。

今後の日本の労働安全においては, 従来のミクロ労働 安全の観点からの対応とともに, 本研究で提案したマク 口労働安全の観点からの対応や研究が重要になると考え られる.

\section{謝辞}

本論文の執筆にあたって，欧州における妥当性確認打 よび機械安全国際規格の規定内容に関する現状につい て, 労働安全衛生総合研究所機械システム安全研究グ ループの齋藤剛上席研究員より資料提供打よび有用な助 言を頂きました。ここに深く感謝いたします。

\section{文献}

1）梅崎重夫, 齋藤剛, 清水尚憲, 芳司俊郎, 岡部康平, 池田 博康, 他. 機械安全規制における世界戦略へ対応するため の法規制等基盤整備に関する調查研究. 厚生労働科学研究 費補助金労働安全衛生総合事業平成 25 年度総括研究年度 終了報告書. 2014年3月.

2）梅崎重夫，齋藤剛，清水尚憲，濱島京子，山際謙太，岡 部康平, 富田一, 池田博康, 他. 機械安全規制に扔ける世 界戦略へ対応するための法規制等基盤整備に関する調查研 究. 厚生労働科学研究費補助金労働安全衛生総合事業平 成 26 年度総括研究年度終了報告書. 2015 年 3 月.

3）濱島京子, 梅崎重夫. 労働安全及び機械安全分野におけ る社会基盤の確立に関する考察一社会システムとしての安 全制御構造一. 電子情報通信学会技術研究報告. 2014; 114(106): $1-4$.

4）日本規格協会. リスクマネジメント一用語. 2010; JIS Q 0073 (ISO Guide 73:2009).

5）日本規格協会．リスクマネジメント一原則及び指針．2010; JIS Q 31000 (ISO 31000:2009).

6）梅崎重夫, 清水尚憲. 産業機械の労働災害分析. 産業安全 研究所特別研究報告. 2005; 33: 53-67.

7）向殿政男監修，安全技術応用研究会編. 国際化時代の機 械システム安全技術. 安全技術応用研究会. 日刊工業新聞 社. $2000 ; 16,79$.

8）鈴木茂夫. CEマーキング制度一主要EC指令とCEマーキン グ一. 工学図書株式会社. 2010; 2 .

9) ISO Guide 78:2008. Safety of Machinery-Rules for Drafting and Presentation of Safety Standards.

10) European Commission Enterprise and Industry. Guide to Application of the Machinery Directive 2006/42/EC. 2010; 2nd Edition.

11）（社）日本機械工業連合会，（株）三菱総合研究所. 平成 17 年度海外に扔ける機械安全に関連する法体系と運用の実 態に関する調查報告書. 日本機械工業連合会；2006.

12）（社）日本機械工業連合会，（株）三菱総合研究所. 平成 21 年度米国に打ける機械安全推進方策の動向に関する調査 
研究報告書. 日本機械工業連合会 ; 2010 .

13）日本規格協会. リスクマネジメントー用語一規格において使 用するための指針. 2003; JIS TR Q 0008 (ISO/IEC Guide 73:2002).

14）日本規格協会. 安全側面一規格への導入指針. 2004; JIS Z 8051 (ISO/IEC Guide 51:1999).

15）梅崎重夫, 清水尚憲, 濱島京子, 他. よく分かる! 管理 監督者のための安全管理技術一管理と技術のココがポイ ントー(基礎編)。日科技連出版社；2011.

16）野口和彦. ISO 31000:2009リスクマネジメント解説と適用 ガイド.リスクマネジメント規格活用検討会編. 日本規格協 会. $2010 ; 18,24,28,34,41,46,47,59$.

17）梅崎重夫, 濱島京子, 池田博康. 食品機械を対象とした 労働災害分析. 労働安全衛生総合研究所安全資料. 2012; JNIOSH-SD-No. 27.

18）梅崎重夫, 濱島京子, 清水尚憲, 板垣晴彦.コンベヤを対
象とした労働災害分析一労働損失日数の活用によるリスクの 定量的評価一. 労働安全衛生研究. 2012; 5(1): 33-44.

19）濱島京子，梅崎重夫，板垣晴彦．粉砕機及び混合機を対象 とした労働災害分析一労働損失日数の活用によるリスクの定 量的評価と比較一. 労働安全衛生研究. 2012; 5(2): 87-97.

[補足 1] 欧州の機械安全に関する法規制および社会制度 については，文献1）にて，日本の労働災害防止対策に 活用する観点から詳しく述べている．特に下記(1)〜(3)の 法規制や社会制度が，欧州の機械安全制度の核心である としている： 1)安全上の必須要求事項である欧州指令と これを補完する体系的な技術仕様書である EN規格, (2) モジュール方式による適合性評価と欧州域内での相互承 認，(3)自己責任に基づき製品の必須要求事項への適合を 自ら宣言するCEマーキング. 


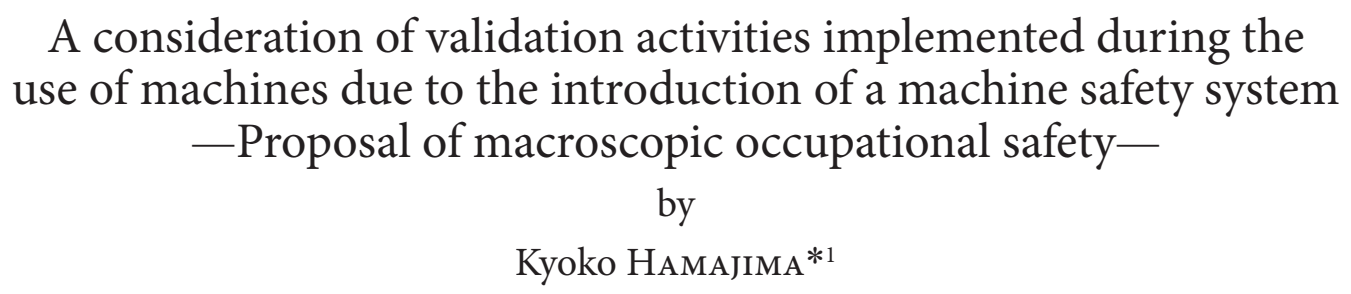

There is the opinion that a European system for machine safety should be introduced in Japan to achieve a desirable level of occupational safety. Occupational safety is secured by adopting a system in which the risk is managed by avoiding, reducing, transferring, and accepting it, after all risks have been considered. Machine safety, meanwhile, is secured by adopting a system in which risks are reduced one by one. The current study proposed a method in which the occupational safety system is incorporated into the machine safety system as a risk-reduction measure; this method makes use of risk management. The theoretical framework used to achieve this was the International Organization for Standardization 31000:2009 "Risk Management-Principles and Guidelines." In this risk management, a system is needed that validates activities for preventing occupational accidents at work sites in order to compensate for inadequacies in the machine safety system relating to occupational accidents. The purpose of this form of risk management is to prepare the social environment to support autonomous safety and health activities, and to develop measures to cope with work-site risks, all in the form of a social system. With this form of risk management, uncertainty within systems and measures must be handled as a risk. This idea differs from that of conventional occupational safety in terms of its understanding of risk. The current study proposed macroscopic and microscopic occupational safety: the former pertains to uncertainty that exists in the social environment surrounding work sites, while the latter pertains to uncertainty that exists in autonomous safety and health activities performed at work sites.

Key Words: occupational safety, safety of machinery, social systems, total optimization, validation

*1 Electrical Safety Research Group, National Institute of Occupational Safety and Health 